\title{
Hypothesis for the mechanics and seismic behaviour of low-angle normal faults: the example of the Altotiberina fault Northern Apennines
}

\author{
Cristiano Collettini \\ Dipartimento di Scienze della Terra, Università degli Studi di Perugia, Italy
}

\begin{abstract}
Widespread mapping of low-angle normal faults in areas of former continental extension continues to prompt debate as to whether such structures may be seismically active at very low dips $\left(\delta<30^{\circ}\right)$ in the upper continental crust. The Northern Apennines provide an example where an active low-angle normal fault (Altotiberina fault, ATF) can be studied. A set of commercial seismic reflection profiles plus deep boreholes have been used to constrain the geometry of the fault at depth. These data have been integrated with a microseismic survey showing that part of the microseismicity $(M<3.0)$ is consistent with the geometry of the ATF as imaged by depth converted seismic reflection profiles. Frictional fault mechanics under Byerlee's friction coefficient and vertical $\sigma_{1}$ (constrained from the inversion of the focal mechanisms) defines the peculiar condition for reactivation of the ATF: small values of differential stress, $\sigma_{1}-\sigma_{3}<28 \mathrm{MPa}$, relatively high value of tensile strength of the fault surrounding rocks $(T \sim 10 \mathrm{MPa})$ and tensile fluid overpressure $P_{f}>\sigma_{3}$ (i.e. $\left.\lambda_{v}>0.93\right)$. The short-lived attainment of $P_{f}>\sigma_{3}$ along small fault portions, in an area characterised by large amounts of $\mathrm{CO}_{2}$, account for the microseismic activity located along the ATF, which occurs on rupture surfaces in the range of $10^{-1}-10^{-3} \mathrm{~km}^{2}$.
\end{abstract}

Key words Northern Apennines - friction - normal faults - microseismicity - fluid pressure

\section{Introduction}

The Northern Apennines consist of a NE verging thrust-fold belt formed as the result of the collision between the European continental margin (Sardinia-Corsica block) and the Adriatic microplate (e.g., Alvarez, 1972; Reutter et al.,

Mailing address: Dr. Cristiano Collettini, Dipartimento di Scienze della Terra, Università degli Studi di Perugia, Piazza dell'Università 1, 06100 Perugia, Italy; e-mail: colle@unipg.it
1980). NE migration of compression is associated with hinterland extension. Geological and geophysical data locate the compressional front, presently active close to the Adriatic coast and the extensional active front near the axial zone of the Northern Apennines (fig. 1). The presence of adjacent sectors of compression and extension (Lavecchia et al., 1994; Mariucci et al., 1999) and the migration with time of the compressionextension pair from the Tyrrhenian sea to the present position can find a possible explanation in the rollback and retreat of a subducting slab (Reutter et al., 1980; Royden and Karner, 1984; Doglioni, 1991; Keller et al., 1994).

The extending sector is characterised by a widespread high heat flow, more than $90 \mathrm{~mW} / \mathrm{m}^{2}$ (Mongelli and Zito, 1991), long-wavelength 

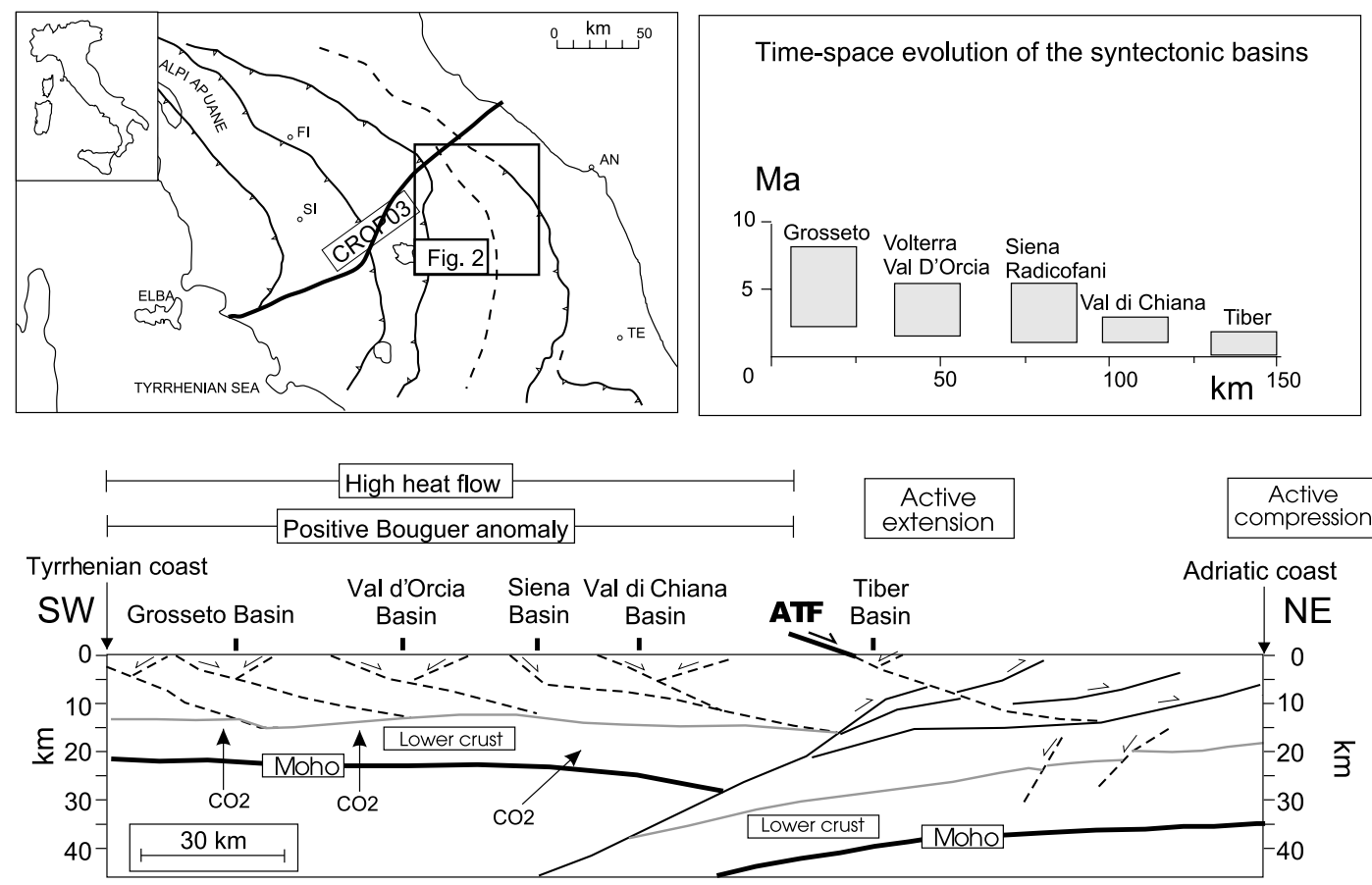

Fig. 1. Schematic crustal-scale cross section along the CROP03 (Barchi et al., 1998a). The profile shows that part of the extension is accommodated by upper-crust, east-dipping LANFs. The extensional processes in the Tyrrhenian Sea and Tuscany have been active enough to favour exhumation accompanied with high heat flow, positive Bouguer gravity anomaly, a shallow Moho, deep release of $\mathrm{CO}_{2}$. Migration of extension from the Tyrrhenian coast to Umbria as calibrated by the time-space evolution of the syntectonic basins (data from seismic reflection profiles Barchi et al., 1998b; Pascucci et al., 1999). In the active region crustal thinning is continuing. Crustal structure is from the CROP03 (Barchi et al., 1998a), heat flow (Mongelli and Zito, 1991), gravity anomaly (Marson et al., 1998), CO release (Chiodini et al., 2000). The position of the Moho is calibrated by deep seismic refraction profiles (Ponziani et al., 1995).

positive Bouguer gravity anomaly, 30-40 mGals, (Marson et al., 1998), a widespread flux of $\mathrm{CO}_{2}$, likely to be related to mantle degassing (Chiodini et al., 2000), a shallow lithosphere/ asthenosphere boundary, $50 \mathrm{~km}$ deep (Suhadolc and Panza, 1989) and a shallow Moho, 20-25 km deep (Ponziani et al., 1995).

The development of extensional deformation within the Northern Apennines is well known (Elter et al., 1975), but the asymmetric character of extension has been only recently revealed. The CROP03 deep seismic reflection profile (Pialli et al., 1998), which crosses the Northern Apennines from the Tyrrhenian to the Adriatic coast, shows that extension within the brittle upper crust is accommodated by a set of major ENE-dipping LANFs, bounding syntectonic basins, associated with antithetic high-angle normal faults (fig. 1). Continuous migration of extension from west to east is well constrained by the age of the syntectonic basins (fig. 1). Extension started in the western part of Tuscany during the Tortonian, then migrated eastward and now is active in the axial zone of the Northern Apennines.

In this paper: 1) the easternmost of these LANFs, the Altotiberina fault (ATF) which is located in the seismically active Umbria region, has been studied by using seismic reflection 
profiles and seismological data; 2) the AndersonByerlee frictional fault mechanics along with the debate related to the LANF argument is extensively revisited; 3) a mechanical model, invoking the local attainment of dramatic fluid overpressures is proposed to explain the microseismic activity of the ATF.

\section{Active extensional faults in Umbria}

Extensional tectonics has been affecting the Umbria region since the upper Pliocene (Ambrosetti et al., 1978). Extension is accommodated by NNW-SSE trending normal faults which bound syntectonic basins (fig. 2). The Tiber basin, infilled by fluvio-lacustrine upper Pliocene-Quaternary syntectonic sediments, is the wider basin of the area and has a longitudinal continuity of more than $100 \mathrm{~km}$. East of the Tiber basin, the axial zone of the Northern Apennines is characterised by intramountain basins possessing sub-polygonal shape and relatively little longitudinal continuity (Gubbio, Gualdo Tadino, Colfiorito, Norcia, Castellucio). In the intra-mountain area the SW dipping $\left(50^{\circ}\right.$ $70^{\circ}$ ) basin-bounding faults severely affect the topography and show an extensional kinematics close to pure dip-slip (Lavecchia et al., 1994; Boncio et al., 1996; Collettini, 2001).

\subsection{Seismic images of normal faults}

Seismic reflection profiles provide a powerful tool to investigate the geometry of the faults up to the seismogenic depth and comparison with seismological data help much to discriminate the active systems.

The subsurface setting of the area has been studied by interpreting and converting to depth a set of nine seismic reflection profiles (Barchi et al., 1999): eight commercial profiles, provided by ENI/AGIP division, and the CROP03 deep seismic reflection profile (see location in fig. 2). The stratigraphy of the study area consists schematically of four major lithological units, from top to bottom: Miocene Turbidites, JurassicOligocene Carbonates, Triassic Evaporites, Permian-Triassic Phyllitic Basement. The

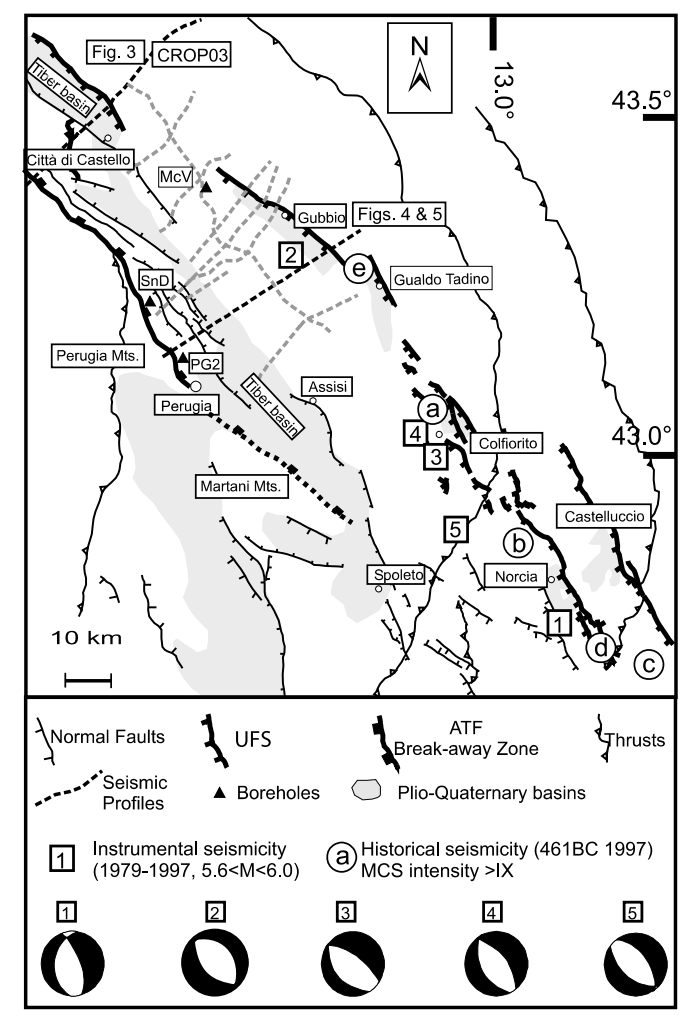

Fig. 2. Schematic structural map of the Umbria region. The map is derived from the compilation of available data and original geological surveys. Instrumental seismicity $5.6<M_{w}<6.0: 1$-September 19,1979 , Norcia earthquake $M_{w}^{w}=5.8 ; 2$-April 24, 1984, Gubbio earthquake $M_{w}=5.6$; 3 -September 26, 1997, 00.33, Colfiorito earthquake $M_{w}=5.7$; 4 - September 26, 1997, 09.40, Colfiorito earthquake $M=6.0 ; 5$-October 14, 1997, Sellano earthquake $M_{w}=5.6$. Focal mechanism solutions $1,3,4$ and 5 CMT; 2 Westaway et al. (1989). Historical seismicity (Boschi et al., 1999) with epicentral intensity greater than IX on the Mercalli-Cancani-Sieberg scale (MCS): a-April 30, 1279, Camerino earthquake; b-December 1, 1328, Norcia earthquake; c-October 7, 1639, Amatrice earthquake.; d-January 14, 1703, Norcia earthquake; e-July 27, 1751, Gualdo Tadino earthquake.

seismic profiles show at least four main seismic markers, calibrated on boreholes data (Bally et al., 1986; Anelli et al., 1994), that can be traced throughout the region and correspond to: Bisciaro 
Fm. (at the base of the Miocene Turbidites), Marne a Fucoidi Fm. (a marly interval within the carbonatic sequence), top of Triassic Evaporites and top of Permian-Triassic Phyllitic Basement.

The main result of the interpretation of the seismic profiles is that the major fault of the study area is an ENE dipping LANF, named Altotiberina fault, ATF, which bounds the Tiber basin (Barchi et al., 1998a). A portion of the CROP03 (Pialli et al., 1998) deep seismic reflection profiles (fig. 3), and a line drawing, derived from a commercial profile (fig. 4) are here reproduced along with their geological interpretations.

In the CROP03 profile (fig. 3) the trace of the ATF is represented by the eastward dipping alignments of the reflectors merging at surface

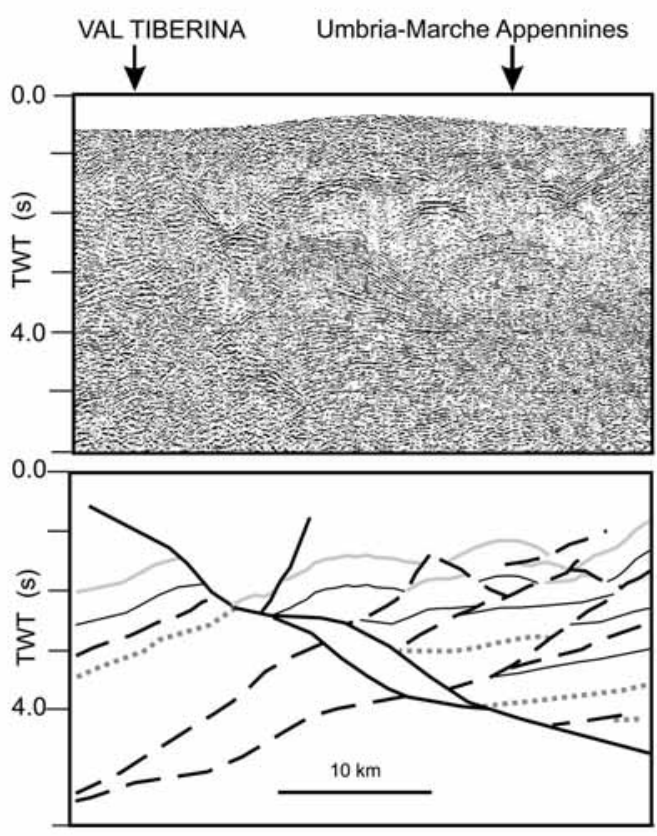

a) - - b) c) d) e)

Fig. 3. Portion of the CROP03 deep seismic reflection profile (see location in fig. 2) and geological interpretation (after Barchi et al., 1998a). a- Normal faults; b-thrusts; c-Marne a Fucoidi Fm.; d-top Evaporites; e-top of Phyllitic basement. into the western margin of the Tiber basin. The alignment of the reflectors deepens towards ENE and reaches a depth of $\sim 5 \mathrm{~s}$ (TWT), roughly corresponding to $13 \mathrm{~km}$, below the Apenninic belt. In the shallower part of the profile, an antithetic normal fault bounding the eastern part of the Tiber basin can also be detected. Along the ATF fault trace, at depth ranging between 2.5 and $3.5 \mathrm{~s}$ (TWT), a lens shaped, east-dipping package of reflectors discloses a mature fault zone, forming an extensional duplex. On the ATF hangingwall the seismic markers effectively depict the previously formed compressional structures of the Apenninic thrust and fold belt, dissected and down-thrown by the normal fault activity. These reflections are strongly interrupted against the eastward dipping reflections representing the ATF and they form sharp angles.

The geometry of the continental Tiber basin (cf. also Collettini et al., 2000) is highlighted in the western and shallower portion of seismic profile of fig. 4 . The asymmetrical shape of the basin is consistent with movements along an eastward dipping normal fault: the Tiber basin results from the activity of a high angle synthetic splay of the ATF, whose break away zone is located $10 \mathrm{~km}$ westward (fig. 2). The structures in the ATF hanging wall show the effects of the compressional tectonics: in particular, the geometry of the Gubbio anticline, with the frontal thrust and the west-dipping normal fault displacing its back-limb, can be recognised.

The tectonic framework of the area is well evidenced in the geological cross section constructed by integrating geological and geophysical data (fig. 5).

The San Donato borehole (Anelli et al., 1994) drilled the ATF close to its breakaway zone where it superposes the Miocene Turbidites of the Marnoso Arenacea Fm. above the Triasssic Evaporites. The surface expression of the ATF is represented by the complex normal fault system mapped at surface in the Perugia Mts. (Minelli, 1992; Brozzetti, 1995) and interpreted as a domino-like structure detached on the ATF (Boncio et al., 1998). The easternmost high-angle splay of the ATF, which bounds the syntectonic Tiber basin, has a maximum throw of $\sim 1.5 \mathrm{~km}$. The age of the sediments infilling the Tiber basin constrain the initiation of the activity of the 

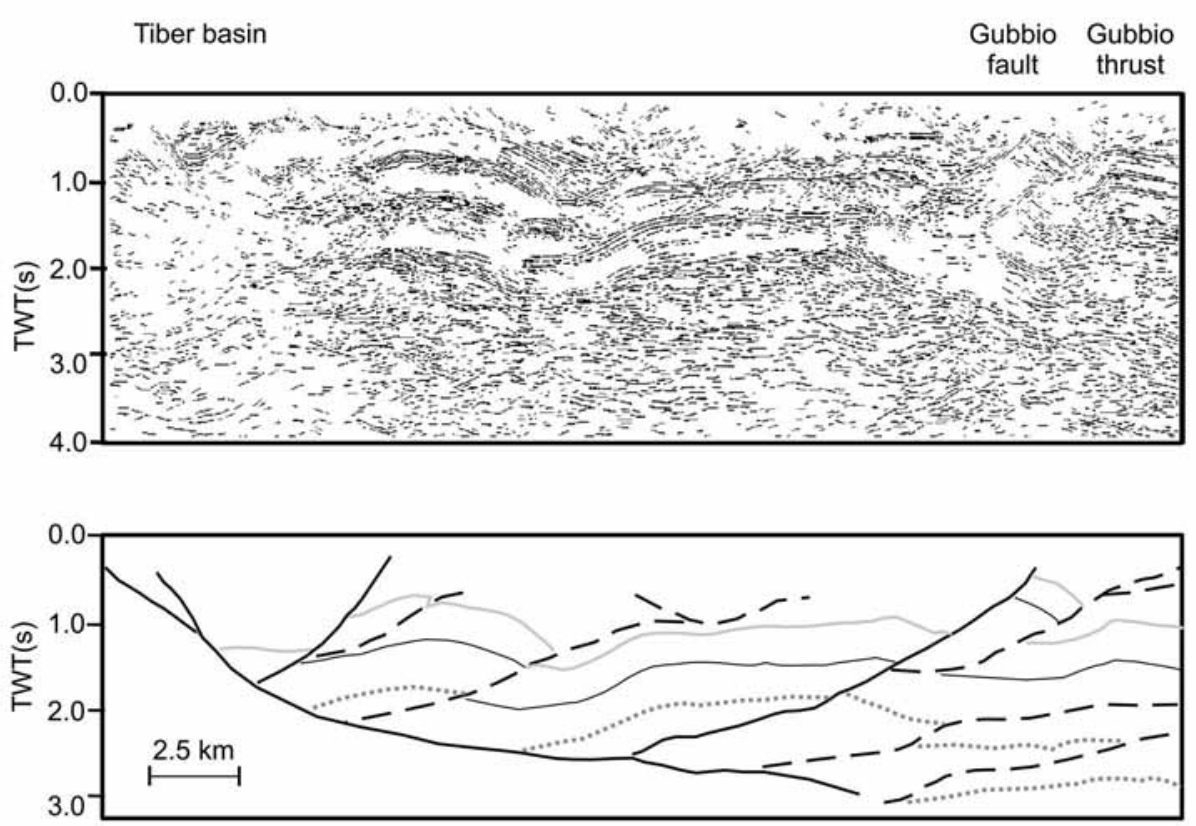

a) $--b)$

c)

d)

e)

Fig. 4. Line drawing and geological interpretation of a seismic profile (modified after Barchi et al., 1999 see location in fig. 1). a-Normal faults; b-thrusts; c-Marne a Fucoidi Fm.; d-top Evaporites; e-top of Phyllitic basement.

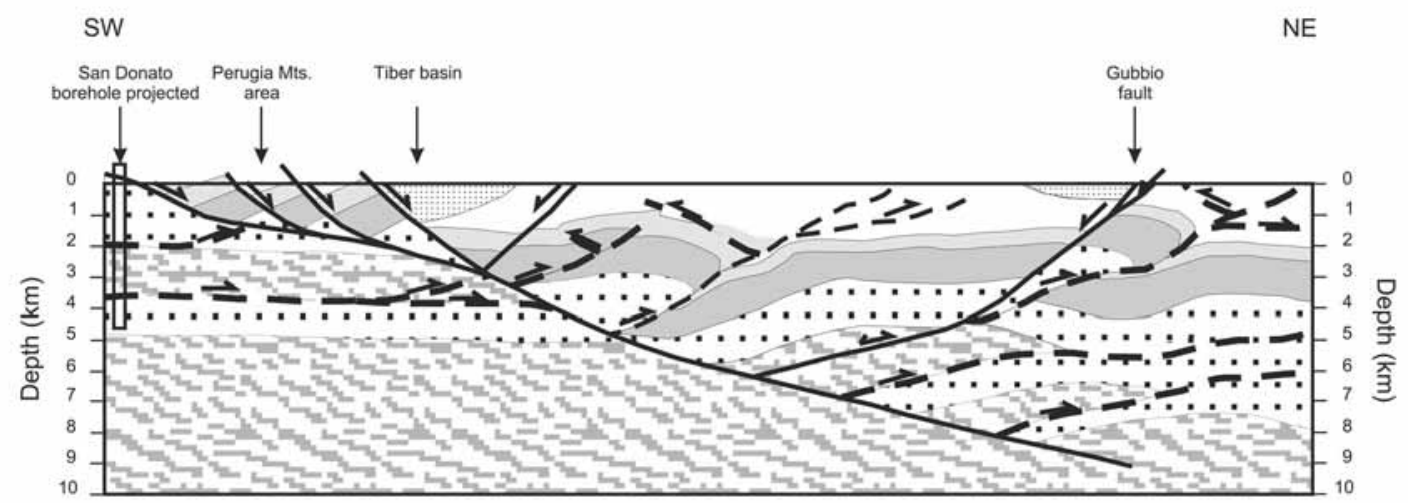

Elil Pliocene-Quaternary neoautochtonous deposits $\square$ Miocene Turbidites $\square \quad$ Upper Cretaceous-Lower Miocene Carbonates $\square$ Lias-Lower Cretaceous Carbonates

Fig. 5. Interpretative geological cross-section through the study area, based on seismic profile of fig. 4, integrating borehole data (Anelli et al., 1994), seismic refraction profile (Ponziani et al., 1995), surface geology data (Minelli, 1992; Brozzetti 1995). 
(a)

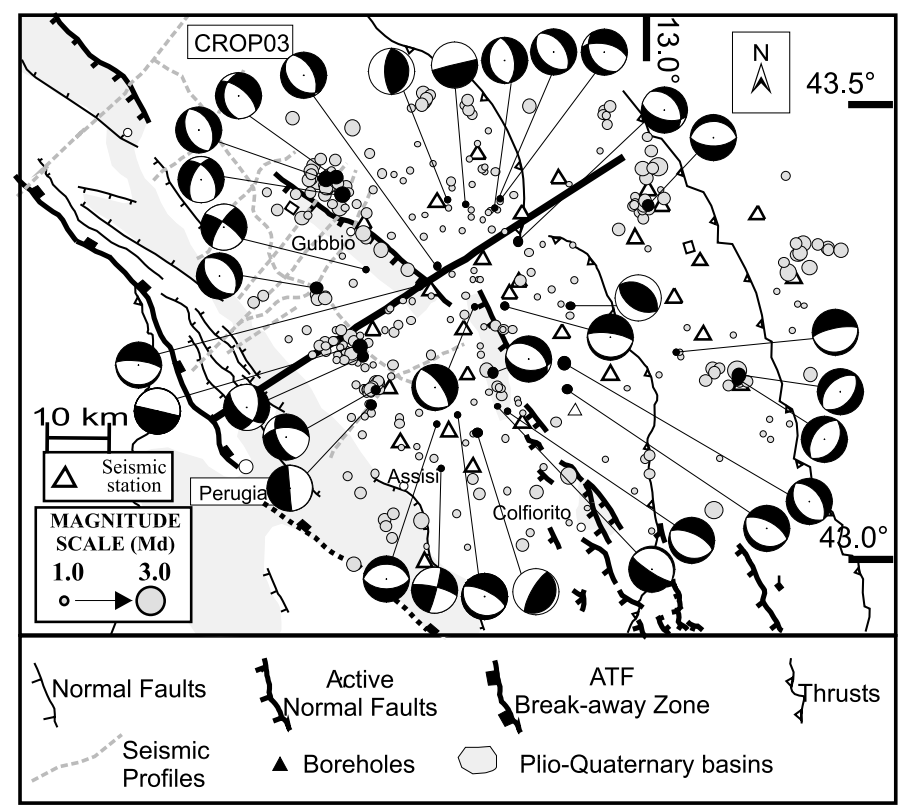

(C)
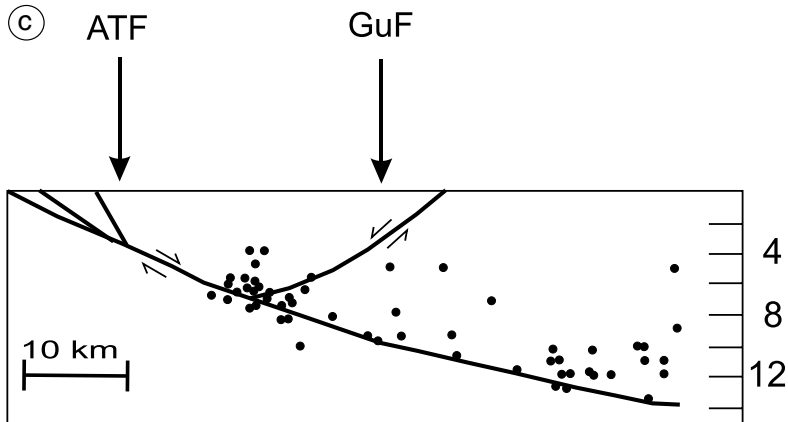

(b)
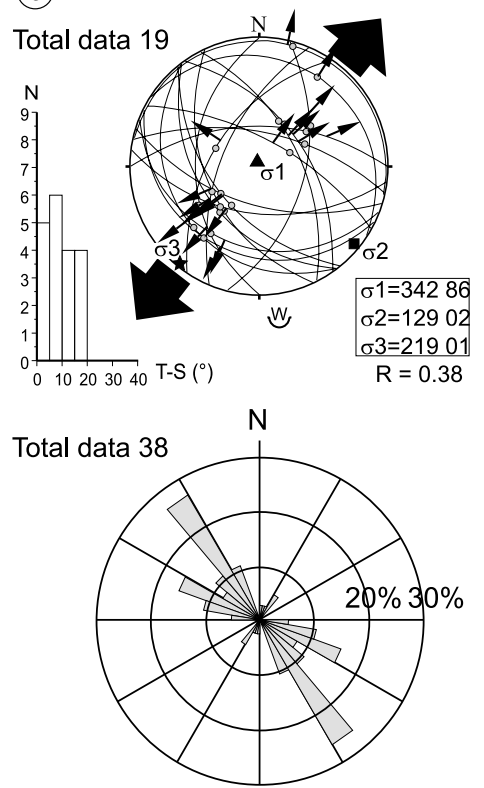

(d)

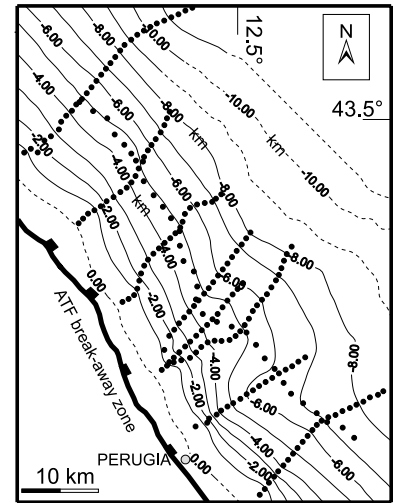

Fig. 6a-d. a) Earthquake locations for the study area recorded by a detailed temporary microseismic survey MayJune 1987, focal mechanisms constrained by more than eight reliable $P$-wave first motion polarities. Hypocentral errors $<2 \mathrm{~km}$ in the $X Y$ plane and $<4 \mathrm{~km}$ in the $Z$ direction (Deschamps et al., 1989; Boncio et al., 2000). b) Summary of stress analysis for the main population of the microearthquake focal mechanisms $(n=19)$ homogeneously distributed in the study area (Boncio et al., 1996, 2000). Projected on the Wulff net are: seismic planes, observed (arrows) and theoretical (dots) slip vectors: note some gently eastward dipping planes. Orientation of the stress tensor, possessing vertical $\sigma_{1}$, form inversion technique (after Boncio et al., 1996, 2000). Rose diagram constructed for the main population of the microearthquakes. c) Plot of the microseismicity on a geological cross section obtained from a depth-converted seismic reflection profile: the events plotted possess errors in focal depths $<1 \mathrm{~km}$ and are located within a band with half-width of $5.0 \mathrm{~km}$. d) 3D reconstruction of the ATF constructed by using depth converted seismic reflection profiles. 
easternmost splay of the ATF to the upperPliocene hence suggesting a time-averaged slip rate of $1 \mathrm{~mm} / \mathrm{yr}$. The total displacement of the fault ranges from 5 to $8 \mathrm{~km}$.

With the exception of the shallower portion, the ATF has a gently dipping attitude $\left(20^{\circ}\right)$; the SW-dipping normal fault which bounds the intramountain basins are antithetic to the ATF. The ATF cuts and displaces the compressional structures inherited by the compressional phase. Seismic reflection profiles constrain the geometry of the ATF over an area of $150 \mathrm{~km}^{2}$ : the fault trends NNW-SSE and has a constant dip $\left(\sim 20^{\circ}\right)$ toward ENE (fig. 6d)

\subsection{Seismotectonic setting}

During the last two decades, three seismic sequences have been recorded along the Umbria Fault System (UFS in fig. 2): Norcia 1979, Gubbio 1984 and Colfiorito 1997-1998 (Deschamps et al., 1984; Haessler et al., 1988; Westaway et al., 1989; Amato et al., 1998). Improved techniques in earthquake recording and location have led to high resolution definition of the Colfiorito sequence but the earlier seismic sequences are less well defined.

The three sequences are characterised by moderate earthquakes $(5.6<M<6.0)$, epicentres located in the proximity of the intramountain basins (fig. 2) and extensional focal mechanism with one nodal plane parallel to the normal faults that border the extensional basins of the area, though this interpretation has been questioned for the Norcia event (see Cello et al., 1997). For each sequence, the aftershock distribution seems to highlight SW dipping nodal planes, with the mainshocks located at the base of the aftershock sequence at depth ranging from 5 to $15 \mathrm{~km}$. The historical seismicity of the region (Boschi et al., 1999), with the strongest events that reach intensity $I=X$, also follows the same NNW-SSE alignment (fig. 2). These data identify the UFS as the active system of the area where the strongest earthquakes occur (e.g., Barchi et al., 2000). The faults within the UFS dip in the range $50^{\circ}-70^{\circ}$ at surface and are antithetic to the ATF in the seismic profiles ( $c f$. also Boncio et al., 2000).
During May-June 1987 a seismic survey (fig. 6a) highlighted the area between Perugia and the Apenninic chain (Deschamps et al., 1989). In a short time interval (2 months), nearly 400 earthquakes, with local magnitude ranging from 0.6 to 3.0, were recorded in the study area. The focal mechanisms (fig. 6a) show the extensional character of the microseismicity, also confirmed by stress inversion technique (Boncio et al., 2000) that constrains a stress tensor with vertical $\sigma_{1}$ and a NE trending sub-horizontal $\sigma_{3}$ (fig. 6b). The slip orientation inferred by seismological data agrees with structural data collected in the Perugia Mts. (Brozzetti, 1995) and with the dip of the fault obtained from seismic reflection profiles. The distribution of the microseismicity plotted on a geological cross section (fig. 6c) shows the hypocenters deepen from west to east, from about $4 \mathrm{~km}$ below the Tiber basin to about $14 \mathrm{~km}$ below the axial zone of the Apenninic belt. Many events fit fairly well with the ATF trace, whereas other earthquakes nucleate in the ATF hanging wall; only a few scattered events are located in the ATF footwall.

Considering the focal mechanisms available, it can be said that most of these earthquakes have focal mechanisms with one nodal plane oriented in the same direction as the ATF, and some of these planes, though without being positively discriminated, are gently eastward dipping (fig. 6b).

Supporting evidence for the seismogenic role of the ATF comes from: a) the hanging wall block has been stretching toward NE since upper Pliocene; b) the SW dipping normal faults antithetic to the ATF are active and seismogenic $(5.0<M<6.0)$. These faults in the seismic profiles do not cut the ATF. Recent seismological data recorded in Northern Umbria by a temporary network show again that the area is characterised by abundant microseismicity (Piccinini, personal comunication) consistent with the ATF trace and its seismically active hanging wall.

It is worth noting that the observed microseismicity is not controlled by temperature; models based on heat flow data for the study area (Pauselli and Federico, 2002) locate the brittle ductile transition between 15 and $20 \mathrm{~km}$. The distribution of the microseismicity has to be 
controlled by some lithological and/or structural factors influencing frictional properties along the fault zone.

\section{Initiation, reactivation and frictional lockup of normal faults}

In a fluid saturated rock-mass with porefluid pressure, $P_{f}$, effective principal stresses are $\sigma_{1}^{\prime}=\left(\sigma_{1}-P_{f}\right)>\sigma_{2}^{\prime}=\left(\sigma_{2}-P_{f}\right)>\sigma_{3}^{\prime}=\left(\sigma_{3}-P_{f}\right)$ (Hubbert and Rubey, 1959). Within intact isotropic crust brittle faults should form in accordance with the Coulomb criterion for shear failure

$$
\tau=C+\mu_{i} \sigma_{n}^{\prime}=C+\mu_{i}\left(\sigma_{n}-P_{f}\right)
$$

where $\tau$ and $\sigma_{n}$ are, respectively, the shear and normal stresses on the failure plane, and $C$ (the cohesive strength) and $\mu_{i}$ (the coefficient of internal friction) are rock material properties. Experimentally determined values for internal friction generally lie in the range $0.5<\mu_{i}<1.0$ (Jaeger and Cook, 1979), leading to the expectation that brittle faults should initiate at $32^{\circ}>\theta_{i}>$ $22^{\circ}$ to the maximum compressive stress $\sigma_{1}$.

For a simple 'Andersonian' extensional regime with $\sigma_{v}=\sigma_{1}$ (Anderson, 1951), normal faults would thus be expected to form with initial dips in the range, $58^{\circ}<\delta<68^{\circ}$. However, with increasing displacement individual faults may rotate within the stress field, especially if they occur within a parallel-dipping set which may 'domino-rotate' to lower dips as regional extension proceeds. Continued reactivation (reshear) of existing cohesionless faults is then governed by Amonton's law

$$
\tau=\mu_{s} \sigma_{n}^{\prime}=\mu_{s}\left(\sigma_{n}-P_{f}\right)
$$

where $\mu_{s}$ is the coefficient of sliding friction. From an extensive series of laboratory friction experiments Byerlee (1978) determined that for most rocks $\mu$ s typically lies in the range $0.6-0.85$. The only prominent exceptions is for material rich in montmorillonite, where the coefficient may be lowered to the range, $0.2<\mu<0.4$ (Morrow et al., 1992); montmorillonite, however, is not stable at temperatures comparable with seismogenic depths. Constraints for friction coefficient, $\mu_{s}=0.6$, also come from recent interpretation of deep boreholes stress measurements (Townend and Zoback, 2000).

For the 2D case where an existing fault containing the $\sigma_{2}$ axis lies at a reactivation angle, $\theta_{r}$, to $\sigma_{1}$, eq. (3.2) may be rewritten in terms of the ratio of effective principal stresses as

$$
\frac{\sigma_{1}^{\prime}}{\sigma_{3}^{\prime}}=\frac{\left(\sigma_{1}-P_{f}\right)}{\left(\sigma_{3}-P_{f}\right)}=\left(\frac{1+\mu_{s} \cot \theta_{r}}{1-\mu_{s} \tan \theta_{r}}\right)
$$

defining the relative ease of shear reactivation for faults oriented at varying angles to $\sigma_{1}$ (Sibson, 1985). The optimal orientation for frictional reactivation, when the stress ratio for reactivation is a positive minimum (fig. 7a) is given by $\theta_{r}^{*}=0.5 \tan ^{-1}\left(1 / \mu_{s}\right)$. As $\theta_{r}$ decreases or increases

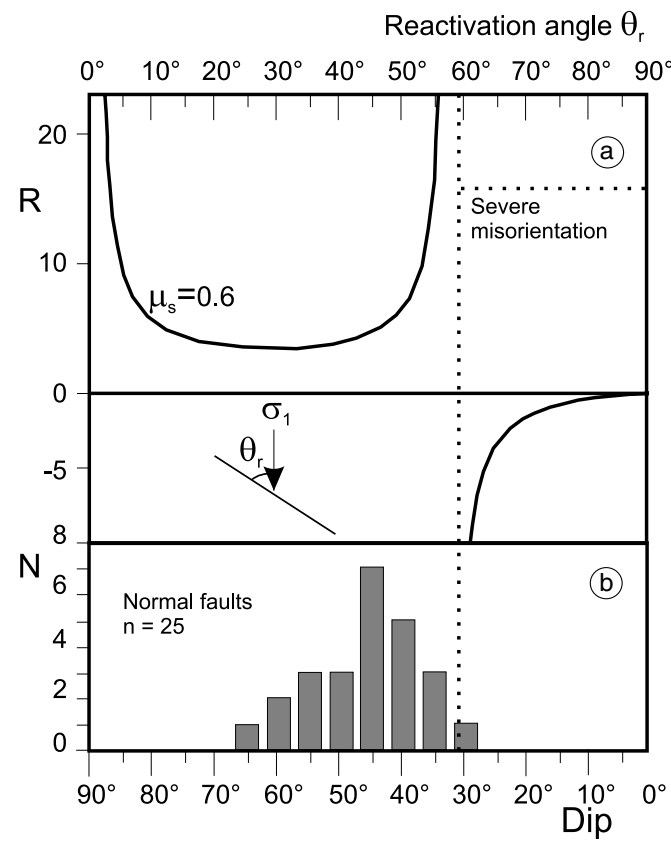

Fig. 7a,b. a) Stress ratio, $R$, for the frictional reactivation of a cohesionless fault plotted against the reactivation angle, $\theta_{r}$, for $\mu_{s}=0.6$ (after Sibson, 1985). b) Histogram of active normal fault dips (after Collettini and Sibson, 2001). 
away from this optimal position, the stress ratio required for reactivation increases. Frictional lock-up $\left(\sigma_{1}^{\prime} / \sigma_{3}{ }^{\prime}=\infty\right)$ occurs when $\theta_{r}=2 \theta_{r}^{*}=\tan ^{-1}$ $\left(1 / \mu_{s}\right)$. In the field of severe misorientation, beyond frictional lock-up, reshear is only possible under the tensile overpressure condition (Sibson, 1990) with $\sigma_{3}^{\prime}=\left(\sigma_{3}-P_{f}\right)<0$.

For Byerlee's (1978) range for rock friction, optimal reactivation occurs when $\theta_{r}=25-30^{\circ}$ (with faults close to their original 'Andersonian' initiation attitudes) and frictional lock-up is expected at $\theta_{r}=50-59^{\circ}$.

The Anderson-Byerlee frictional fault mechanics (vertical $\sigma_{1} ; \mu_{s}=0.6$ ) agrees with the dip range of active normal faults capable of generating big ruptures (fig. 7b): compilation of dip estimates prepared from focal mechanisms of shallow intracontinental normal-slip earthquakes $(M>5.5$; slip vector raking $90 \pm 30^{\circ}$ in the fault plane) where the rupture plane is unambiguously discriminated extends from $65^{\circ}>\delta>30^{\circ}$ (Collettini and Sibson, 2001). Due to the impossibility of sustaining $P_{f}>\sigma_{3}$ no big ruptures occur on normal faults dipping less than $30^{\circ}$.

\section{The debate on low-angle normal faults}

The presence of low-angle normal faults, LANFs, $\left(\operatorname{dip}<30^{\circ}\right)$ has been extensively documented in areas of continental extension. LANFs were first recognised in the Basin and Range province (Wernicke, 1981; Lister and Davis, 1989 for a comprehensive review) and then documented in other areas: in Greece (Lister et al., 1984; Rigo et al., 1996; Sorel, 2000); in the East African Ridge System (Morley, 1999) in the Northern Apennines (Carmignani and Klingfield, 1990; Jolivet et al., 1998; Pialli et al., 1998). Though the LANFs topics is well covered in literature, it is still full of controversies.

First, how do LANFs form (i.e. is their lowangle attitude an original feature or the result of rotation)? According to Anderson-Byerlee frictional fault mechanics, normal faults initiate at dips $\sim 60^{\circ}$ than domino rotate to frictional lockup angles, $40^{\circ}-30^{\circ}$ (Sibson, 1985). Dips lower than lockup angle would be achieved by domino rotation produced by successive normal fault sets (Proffett, 1977), or isostatic adjustments producing footwall flexure and uplift (Wernicke and Axen, 1988). In marked contrasts some field observations constrain initiation and movements along LANFs at dips similar to their present attitude (Scott and Lister, 1992; John and Foster, 1993). Very low dips have been also explained as the result of dramatic departures from the Andersonian state of stress induced by severe topography (Abers et al., 1997) or high shear stress at the base of the brittle crust (Westaway, 1999).

Second, can displacement be accommodated by LANFs and how (seismic, microseismic, aseismic)? There are no definitive examples of $\mathrm{M}>5.5$ normal slip earthquakes on fault dipping less than $30^{\circ}$ (fig. $7 \mathrm{~b}$ ). On the contrary three possibly low-angle ruptures $\left(10^{\circ}<\delta<30^{\circ} ; 6.0<\right.$ $<M_{w}<6.8$ ), though without positive discrimination, have been adduced to a LANF active in the Papua New Guinea (PNG) region (Abers, 1991; Wernicke, 1995): the lack in the contemporary seismic record of moderate and large ruptures on LANFs has been suggested to be due to their long recurrence intervals (Wernicke, 1995). In considering the PNG earthquakes as genuine ruptures on LANFs two points must be considered. Firstly, it can be said that depth converted seismic profiles crossing the same area show the seismogenic low angle detachment dipping $\sim 30^{\circ}$ (Taylor et al., 1999). Secondly, it should be noted that in some peculiar conditions (i.e. areas of high extensional rates) shear stress at the base of the brittle layer can be high enough to perturb the stress field in the upper crust with the consequent rotation of the $\sigma_{1}$ trajectories (Westaway, 1999); in this case a LANF is not severely misoriented for reactivation and can nucleate moderate earthquakes.

More recently, there have been suggestions of a microseismically active low-angle detachment dipping $c a .15^{\circ}$ north beneath the rapidly extending Gulf of Corinth, Greece (Rietbrock et al., 1996; Rigo et al., 1996), though this interpretation has since been questioned (Hatzfeld et al., 2000).

\section{Mechanical consideration on ATF}

In order to discuss the mechanical conditions to explain the microseismic activity of the ATF $\left(\operatorname{dip} 20^{\circ}\right.$ ) within a regional stress field charac- 
terised by a vertical $\sigma_{1}$ (e.g., Boncio et al., 1996; Chiaraluce et al., 2001), frictional fault mechanics has been applied.

Since most of the earthquakes are due to local frictional instability on existing faults (Scholz, 1998) and since the ATF shows a normal slip kinematics, $2 \mathrm{D}$ reactivation theory has been applied.

The analysis seeks to speculate on the conditions for reactivation of the ATF, using Mohr circles in a Coulomb Griffith failure diagram integrated with the re-shear condition (e.g., Brace, 1960; Hancock, 1985). Under vertical trajectories of $\sigma_{1}$ it is analysed with Mohr circles the state of stress necessary for reactivation of the plane of weakness as a function of differential stress $\left(\sigma_{1}-\sigma_{3}\right)$, reactivation angle $\left(\theta_{r}\right)$ and fluid pressure $\left(P_{f}\right)$. circle

To do this, in the parametric equations of a

$$
\begin{gathered}
x=a-r \cos 2 \alpha \\
y=r \sin 2 \alpha \quad 0<\alpha<90^{\circ}
\end{gathered}
$$

it is written

and

$$
r=1 / 2\left(\sigma_{1}-\sigma_{3}\right)
$$

$$
a=\sigma_{3}^{\prime}+1 / 2\left(\sigma_{1}-\sigma_{3}\right) \text {. }
$$

From eq. (3.3), the values of differential stress, $\left(\sigma_{1}-\sigma_{3}\right)$, and effective least principal stress, $\sigma_{3}{ }^{\prime}$, have been written (Sibson, 2000) as

$$
\begin{aligned}
\left(\sigma_{1}-\sigma_{3}\right) & =\frac{\mu_{s}\left(\tan \theta_{r}+\cot \theta_{r}\right)}{\left(1+\mu_{s} \cot \theta_{r}\right)} \rho g z\left(1-\lambda_{v}\right) \\
\sigma_{3}^{\prime} & =\frac{1-\mu_{s} \tan \theta_{r}}{1+\mu_{s} \cot \theta_{r}} \rho g h\left(1-\lambda_{v}\right)
\end{aligned}
$$

By the eqs. (5.1)-(5.3) and (5.4), is possible to evaluate with Mohr circles the conditions for reactivation of the ATF as a function of the reactivation angle $\theta_{r}$, depth and fluid pressure.

For the intact rock failure envelope in the compressional field $\mu_{i}=0.75$ has been assumed, corresponding to the mid value for the internal friction coefficient $\left(0.5<\mu_{i}<1.0\right)$ ( Jaeger and Cook, 1979). For the re-shear condition the friction coefficient $\mu_{s}=0.6$ has been assumed, the lower end-member of the Byerlee (1978) range.

The average density of the crust $\rho$ is assumed to be $2650 \mathrm{~kg} / \mathrm{m}^{3}$ and $g$ is the gravitational acceleration. The pore fluid factor $\lambda_{v}$ represents the ratio between fluid pressure $P_{f}$ and the lithostatic stress $\left(\sigma_{v}=\rho g z\right)$ assumed to coincide with $\sigma_{1}$. Hydrostatic fluid pressure is represented by $\lambda=0.4$ while lithostatic by $\lambda=1.0$.

Figure 8a-c represents the computed Mohr circles for a fault dipping $20^{\circ}$, corresponding to $\theta_{r}=70^{\circ}$, for different values of the pore fluid factor, at $10 \mathrm{~km}$ of depth and for a tensile strength of the rocks enclosing the fault $T \sim 10$ MPa.

Under these boundary conditions, the reactivation of the ATF is met only for low values of differential stress $\left(\sigma_{1}-\sigma_{3}<28 \mathrm{MPa}\right)$ and quasi lithostatic fluid pressures $\left(\lambda_{v}>0.93\right)$, circle 1 not intercepting neither the Griffith parabola nor the Coulomb criteria.

For lower values of the pore fluid factor $\left(\lambda_{v}<0.93\right)$ the differential stress is higher (eq. (5.3)) and $\sigma_{3}^{\prime}$ is negative for $\theta_{r}=70^{\circ}$ (eq. (5.4)); under these conditions the ATF cannot be reactivated. In fact, the situations represented by circles 2 and 3 cannot be reached. Figure $8 b$ represents the fault loading, assumed to be induced mainly by the increase in fluid pressure, for a differential stress equal to the diameter of circle 2. Before reaching the condition for reactivation of the ATF (circle 2, fig. 8b), extensional fractures or extensional-shear fractures occur as soon as the Mohr circle intercepts the Griffith parabola (e.g., point E on fig. 8b). This occurs for all values $0.86<\lambda_{v}<0.93$. For greater values of differential stress (circle 3 ), a new 'Andersonian' fault develops as soon as the Mohr circle intercepts the Coulomb criterion (point $\mathrm{C}$ on fig. 8c), and this happens for all values $\lambda_{v}<0.86$.

It has been tested the sensitivity of the calculations to the assumed friction coefficients, within the «Byerlee law», and to different depths: under the conditions required for reactivation of the ATF, the simulations are modestly sensitive to these parameters. 

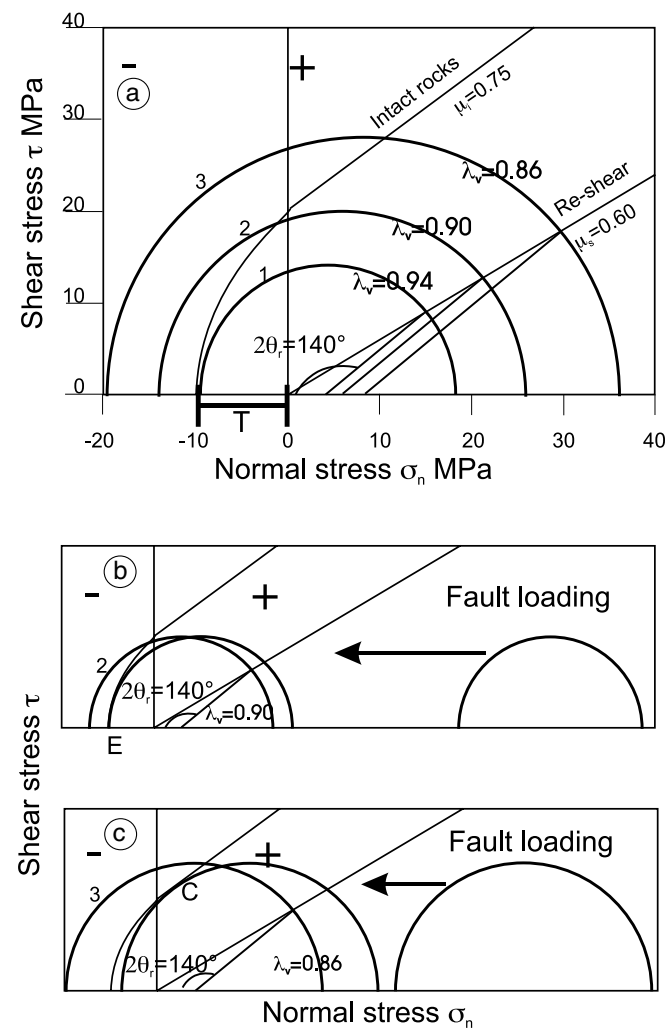

Fig. 8a-c. a) Differential stress $\left(\sigma_{1}-\sigma_{3}\right)$, required for reactivation of the ATF, $\theta_{r}=70^{\circ}$, under a pore fluid factor $\lambda_{v}=0.94,0.90,0.86$, tensile strength of the rock $T=10 \mathrm{MPa}$, plotted in a composite Coulomb-Griffith diagram integrated with the re-shear condition of shear stress, $\tau$, against normal stress $\sigma_{n}$. Only circle 1 represents the conditions for reactivation of the ATF. $\mathrm{b}, \mathrm{c})$ Fault loading mainly induced by the increase of fluid pressure starting from differential stress values represented by circles 2 and 3. b) The Mohr circle intercepts the Griffith parabola at point $\mathrm{E}$, leading to the formation of extensional fractures before reaching the condition for reactivation of ATF (circle 2). c) The Mohr circle intercepts the Coulomb criterion at point $\mathrm{C}$, leading to the formation of a new 'Andersonian' fault before reaching the condition for reactivation of ATF (circle 3).

The mechanical analysis says that the ATF can be reactivated only in peculiar circumstances: low differential stress, $T \sim 10 \mathrm{MPa}$ and high fluid pressure in particular. In the next two paragraphs the specialised circumstances that in the study area may lead to localised fluid overpressures will be discussed.

\subsection{Local short lived attainment of tensile fluid overpressure a possible explanation for small ruptures}

As discussed previously, the key issue for reactivation of the ATF is the attainment of the tensile overpressure condition $P_{f}>\sigma_{3}$ (i.e. $\left.\lambda_{v}>0.93\right)$.

As a consequence of slip, which produces grain comminution, porosity collapse and alteration of clay-rich material from the Phyllitic basement, the ATF represents an impermeable horizon trapping fluids coming from deeper levels favouring fluid overpressures. Moreover, the Phyllitic fault gouge itself can generate water from dehydration reactions (Faulkner and Rutter, 2001).

It is unlikely, however, to sustain tensile fluid overpressure, $P_{f}>\sigma_{3}$, for wide fault portions. First, fluid loss through hydraulic extension fracturing limit the sustainability of the tensile overpressure condition required for reactivation. Second, an increase in permeability under low effective stress has been documented by laboratory experiments (Seront et al., 1998). Third, the load-weakening behaviour for normal faulting induced by the preseismic decrease of the mean stress favours the increase in permeability (Sibson, 1993).

These considerations suggest that the overpressure condition is likely to develop only in small portions of the ATF (fig. 9) and for a short time, being a possible explanation for the microseismic activity $(1<M<3)$ recorded along the fault and involving rupture surfaces in the order of $10^{-1}-10^{-3} \mathrm{~km}^{2}$ (Sibson, 1989). The impossibility of sustaining the tensile overpressure condition over wide fault portions would prevent the nucleation of big ruptures $(M>5.5$; rupture dimensions $c a .5 \mathrm{~km}$ ) on normal faults dipping less than $30^{\circ}$ ( $c f$. fig. 7a,b).

Dealing with the influence of fluid pressure in rupture nucleation and propagation, Miller et al. (1996) proposed a model coupling shear stress and high fluid pressure; the increase in fluid 


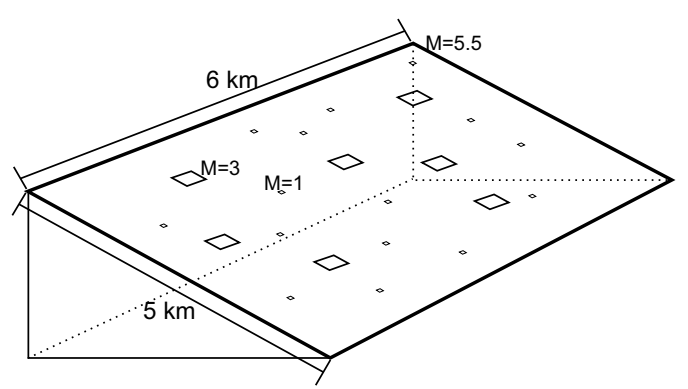

Fig. 9. Cartoon showing the rupture dimensions for a $M=1, M=3, M=5.5$ earthquake. The tensile fluid overpressure condition is sustained only along small fault portions capable of generating microseismicity.

pressure within discrete cells creates zones of low effective stress which produce slip. The propagation of ruptures toward the other cells and thus the possibility to create earthquakes of different magnitudes, is a function of the state of stress of the surrounding areas. Pressurised $\left(P_{f}>\sigma_{3}\right)$ small portions of the ATF, characterised by very low effective stress, can slip. When the slip takes place, it is unlikely to propagate in the surrounding regions because of: 1) strain hardening and velocity hardening of the phyllitic gouge (Faulkner and Rutter, 2001); 2) reduced rupture propagation rates on low angle normal faults (Ofoegbu and Ferrill, 1998).

\subsection{Why is there fluid overpressure in an extending crust?}

Although fluid overpressures in extensional environments are not the rule, the study area represents a peculiar case. High flow rates of gas emission have been documented in the western sector of the Tiber basin with isotopic signatures suggesting deep source (Vasselli et al., 1997; Minissale et al., 2000). This non-volcanic mantle derived $\mathrm{CO}_{2}$ flux is widespread in Central Italy (see also fig. 1) and extremely vigorous $\left(1-3 \cdot 10^{11} \mathrm{~mol} \cdot \mathrm{yr}^{-1}\right)$ with maximum fluxes in the order of $0.2 \mathrm{~m}^{3} \cdot \mathrm{m}^{2} \cdot \mathrm{yr}^{-1}$ (Chiodini et al., 2000). The $\mathrm{CO}_{2}$ rich fluids on their ascent are likely to be entrapped when encounter stratigraphical (e.g., Evaporites or Phyllitic basement) or structural seal (e.g., ATF). At the beginning, $\mathrm{CO}_{2}$ tends to be dissolved in the pore water present at the base of the seal (fig. 10a). The increase in $\mathrm{CO}_{2}$ concentration leads to the formation of a free gas phase (Chiodini et al., 1999) as soon as the total pressure of the reservoir (roughly corresponding to $\mathrm{pCO}_{2}$ ) exceeds pore fluid pressure at the base of the seal. This process produces gas bubbles (fig. 10b) that add to pore pressure and favour the attainment of the tensile overpressure conditions required for reactivation. The consequent slip on the fault creates permeability with post seismic fluid and gas discharge. This process accounts both for the presence in the western margin of the Tiber basin of focussed vents and for the high pressure gas pockets documented in the deep drilling of the region (Chiodini et al., 1999). It is worth noting that the San Donato borehole, before being stopped for fluid overpressure, encountered $\mathrm{pCO}_{2}$ of about $100 \mathrm{MPa}$ at $4.7 \mathrm{~km}$ depth (Chiodini and Cioni, 1989) corresponding to a pore fluid factor at least $\lambda_{v}=0.85$.

Other examples of high fluid pressures in extensional environments have been documented by fluid inclusion studies in correspondence with

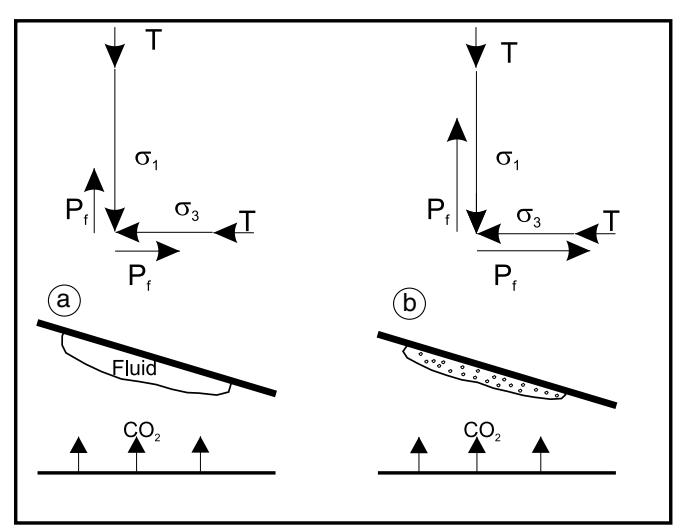

Fig. 10a,b. Schematic model for the attainment of tensile fluid overpressure. a) Deep emissions of $\mathrm{CO}_{2}$ rich fluids encounter a fluid rich reservoir below a structural seal (e.g., ATF). At the beginning $\mathrm{CO}_{2}$ tends to be dissolved within the fluid. b) Increasing concentration of $\mathrm{CO}_{2}$ leads to gas bubble formation within the reservoir favouring the attainment of the tensile fluid overpressure $P_{f}>\sigma_{3}$. 
exhumed seismogenic normal faults in Nevada and Utah (Parry and Bruhn, 1990), and a pore fluid factor of 0.95 has been measured from well data in extending crusts beneath shale sequences in the Gulf Coast Basin (Bradshaw and Zoback, 1988).

\section{Discussion}

In the study area, the strongest seismicity, represented by moderate extensional earthquakes $(5.0<M<6.0)$, is related to a set of SW dipping normal faults which border the Quaternary intramountain basins of the area. These faults dipping at the surface in the range of $50^{\circ}-70^{\circ}$ are antithetic to an ENE-dipping LANF (ATF), whose geometry has been reconstructed matching surface geology with boreholes data and seismic reflection profiles. The fault has an average dip of $20^{\circ}$ and shows a good correlation with the microseismicity of the area. The application of reactivation theory (Sibson, 1985, 1990) under vertical trajectories of $\sigma_{1}$, suggests that the ATF can be seismically reactivated only in specialised circumstances, characterised by tensile fluid overpressure, $P_{f}>\sigma_{3}$, (i.e. $\left.\lambda_{v}<0.93\right)$. This condition is difficult to maintain and it is likely to be sustained only for a small fault portion which can produce microearthquakes.

Friction coefficient too may influence the dip range of severely misoriented faults. If for some reason (not well documented by laboratory or borehole data, but see Townend and Zoback, 2001) the fault possesses very low friction coefficient at seismogenic depths (e.g., $\mu_{s} \sim 0.35$ at depth $>5 \mathrm{~km}$ ), a $20^{\circ}$ dipping normal fault is not in the field of severe misoriented fault hence in a condition to be reactivated without invoking the tensile fluid overpressure condition $\left(P_{f}>\sigma_{3}\right)$.

In the peculiar situation of the Northern Apennines, large emissions of fluids, probably related to mantle degassing phenomena (Chiodini et al., 2000), are likely to be the major cause for the weakening mechanism of the ATF. When these fluids in their ascent meet the ATF, they can be entrapped in small fault portions. The continuous $\mathrm{CO}_{2}$ flux forms gas bubbles that add to pore pressure and favours the attainment of localised overpressures which lead to the nu- cleation of small earthquakes. In any case, the microseismicity recorded along the ATF cannot account for the displacement of the fault $(2 \mathrm{~km}$ for the easternmost splay of the ATF in the upper Pliocene-Quaternary, i.e. $1 \mathrm{~mm} / \mathrm{yr}$ ) part of which is presumably accommodated aseismically. According to these considerations, the ATF would represent a creeping LANF, with most of its trace within the Phyllitic basement, producing part of its displacement aseismically and in some peculiar circumstances, nucleating microearthquakes as a consequence of local fluid overpressures.

This seismic behaviour is in agreement with the mode of failure for a phyllosilicate-rich gouge found from laboratory experiments (Faulkner and Rutter, 2001). Rubin et al., (1999) also documented that faults which creep largely aseismically, simultaneously produce abundant microearthquakes, and the total slip represented by the earthquakes amounts to only a small fraction of the long term observed slip rate.

\section{Acknowledgements}

I thank Massimiliano Barchi and Rick Sibson for discussions, Carlo Cardellini and Giovanni Chiodini for help on the $\mathrm{CO}_{2}$ topic. This research was supported by MIUR01 UR Perugia, Massimiliano Barchi grant.

\section{REFERENCES}

ABERS, G.A. (1991): Possible seismogenic shallow-dipping normal faults in the Woodlark-D'Entrecasteaux extensional province, Papua New Guinea, Geology, 1, 1205-1208.

ABERS, G.A., C.Z. MutTER and G. FANG (1997): Shallow dips of normal faults during rapid extension: Earthquakes in the Woodlark-D'Entrecasteaux rift system, Papua New Guinea, J. Geophys. Res., 102, 15301-15317.

Alvarez, W. (1972): Rotation of the Corsica-Sardinia microplate, Nature, 248, 309-314.

Amato, A., R. Azzara, C. Chiarabba, G. B. Cimini, M. Cocco, M. Di Bona, L. MARgheriti, S. MaZzA, F. Mele, G. Selvaggi, A. Basili, E. Boschi, F. Courboulex, A. Deschamps, S. Gaffet, G. Bittarelli, L. Chiaraluce, D. Piccinini and M. RIPEPE (1998): The 1997 Umbria-Marche, Italy, earthquake sequence: a first look at the main shocks and aftershocks, Geophys. Res. Lett., 25, 2861-2864. 
Ambrosetti, P., M.G. Carboni, M.A.Conti, A.CoSTANTINI, D.EsU, A. Gadin, O.GirotTi, A. LAZ ZAROTTI, R. MAZZANTI, U. NICOSIA, G. PARISI and F. SANDRELLI (1978): Evoluzione paleogeografica e tettonica dei bacini tosco-umbro-laziali nel Pliocene nel Pleistocene inferiore, Mem. Soc. Geol. Ital., 19, 573-580.

Anderson, E.M. (1951): The Dynamics of Faulting (Edinburgh, Oliver and Boyd), 2nd ed., pp. 206.

ANelli, L., M. GorzA, M. PIERI and M. Riva (1994): Subsurface well data in the Northern Apennines (Italy), Mem. Soc. Geol. Ital., 48, 461-471.

BALly, A.W., L. BurbI, C. COOPER and L. CHELARDONI (1986): Balanced sections and seismic reflection profiles across the Central Apennines, Mem. Soc. Geol. Ital., 35 , 257-310.

BARCHI, R.M., G. Minelli and G. PiAlli (1998a): The CROP 03 profile: a synthesis of results on deep structures of the Northern Apennines, Mem. Soc. Geol. Ital., 52, 383-400.

BARChI, M.R., A. De FeYter, M.B. Magnani, G. Minelli, G. PIALLI and M. SOTERA (1998b): Extesional tectonics in the Northern Apennines (Italy): evidence from the Crop 03 deep seismic reflection line, Mem. Soc. Geol. Ital., 52, 527-538.

BARChi, M.R., S. PAOlaCCI, C. PAuselli, G. Pialli and S. MERLINI (1999): Geometria delle deformazioni estensionali recenti nel bacino dell'Alta Val Tiberina fra S. Giustino Umbro e Perugia: evidenze geofisiche e considerazioni geologiche, Boll. Soc. Geol. Ital., 118, 617-625.

BARChI, M.R., F. Galadini, G. LAVECCHIA, P. Messina, A.M. MichetTi, L. PeruzzA, A. Pizzi, E. TONDI and E. VITTORI (2000): Sintesi sulle Conoscenze delle Faglie Attive in Italia Centrale, Gruppo Nazionale per la Difesa dei Terremoti, pp. 62

Boncio, P., F. BRozZeTti and G. LAVECCHIA (1996): State of stress in the Northern Umbria-Marche Apennines (Central Italy): inferences from microearthquake and fault kinematics analyses, Ann. Tectonicae, 10, 80-97.

Boncio, P., F. BROZZETTI, F. PONZIANI, M.R. BARCHI, G LAVECCHIA and G. Pialli (1998): Seismicity and extensional tectonics in the Northern Umbria-Marche Apennines, Mem. Soc. Geol. Ital., 52, 539-555.

Boncio, P., F. Brozzetti and G. LAVEcchia (2000): Architecture and seismotectonics of a regional lowangle normal fault zone in Central Italy, Tectonics, $\mathbf{1 9}$, 1038-1055.

Boschi, E., E. Guidoboni, G. Ferrari, D. Mariotti, G. VALENSISE and P. GASPERINI (2000): Catalogue of strong Italian earthquakes from 461 B.C. to 1997, Ann. Geofis., 43 (4), pp. 268, with full database on CD-ROM (http:// www.ingv.it/).

BRACE, W.F. (1980): Permeability of Crystalline and Argillaceous rocks, Int. J. Rock. Mech. Min. Sci. Geoch. Abst., 17, 241-251.

BRADSHAW, G.A. and M.D. ZOBACK (1988): Listric normal faulting, stress refraction, and the state of stress in the Gulf Coast basin, Geology, 16, 271-274.

BrozzetTI, F. (1995): Stile deformativo della tettonica distensiva nell'Umbria Occidentale: l'esempio dei
Massicci Mesozoici Perugini, Studi Geologici Camerti, 1, 105-119.

ByerleE, J. (1978): Friction of Rocks, Pageoph., 116, 615-626.

CARMignani, L. and R. KLINGFiEld (1990): Crustal extension in the Northern Apennines: the transition from compression to extension in the Alpi Apuane core complex, Tectonics, 9, 1275-1303.

Cello, G., S. Mazzoli, E. Tondi and E. Turco (1997): Active tectonics in the Central Apennines and possible implications for seismic hazard analysis in Peninsular Italy, Tectonophysics, 272, 43-68.

Chiaraluce, L., W.L. Ellsworth, C. ChiarabBa and M. COCCO (2001): Imaging fault geometries with highresolution seismicity data in a complex normal faulting setting in the Central Apennines, Italy, Fall Meeting, San Francisco 10-14 December 2001, Am. Geophys. Un.

Chiodini, G. and R. CIONI (1989): Gas geobarometry for hydrothermal systems and its application to various Italian geothermal areas, Appl. Geochem., 4, 564-572.

Chiodini, G., F. Frondini and F. PonZIAni (1995): Deep structures and carbon dioxide degassing in Central Italy, Geothermics, 1, 81-94.

Chiodini, G., F. Frondini, D.M. Kerrick, J. Rogie, F. PAREllo, L. PERUZZI and A.R. ZANZARI (1999): Quantification of deep $\mathrm{CO}_{2}$ fluxes from Central Italy. Examples of carbon balance for regional aquifers and soil diffuse degassing, Chem. Geol., 159, 205-222.

Chiodini, G., F. Frondini, C. CARDELlini, F. PARELlo and L. PERUZZI (2000): Rate of diffuse carbon dioxide Earth degassing estimated from carbon bilance of regional aquifers: the case of Central Apennine, Italy, J. Geophys. Res., 105, 8423-8434.

Collettini, C. (2001): Architecture, geometry and mechanics of seismogenic normal faults in the Northern Apennines, Ph.D. Thesis, University of Perugia, pp. 199.

Collettini, C. and R.H. SiBSON (2001): Normal faults normal friction?, Geology, 29, 927-930.

Collettini, C., M.R. BARChi, C. PAuselli, C. Federico and G. Pialli (2000): Seismic expression of active extensional faults in Northern Umbria (Central Italy), in The Resolution of Geological Analysis and Models for Earthquake Faulting Studies, edited by G. CELLO and E. TONDI, J. Geodyn., 29, 309-321.

Deschamps, A., G. IIANNACCONE and R. SCARPA (1984): The Umbrian earthquake (Italy) of 19 September 1979, Ann. Geophysicae, 2 (1), 29-36.

DESCHAMPS, A., R. SCARPA and G. SElVAGgi (1989): Analisi sismologica del settore settentrionale dell'Appennino umbro-marchigiano, GNGTS 8th Conference, 1, 9-15.

DoGLIONI, C. (1991): A proposal of kinematic modelling for W-dipping subductions. Possible applications in the Tyrrhenian-Apennines system, Terra Nova, 3, 423-434.

Elter, P., G. Giglia, M. Tongiorgi and L. Trevisan (1975): Tensional and compressional areas in the recent (Tortonian to Present) evolution of the Northern Apennines, Boll. Geofis. Teor. Appl., 17, 3-18.

FAULKNER, D.R. and E.H. RutTER (2001): Can the maintenance of overpressured fluids in large strike-slip fault zones explain their apparent weakness?, Geology, 29, 503-506. 
HaEssler, H., R. GaUlon, L. Rivera, R. CONSOle, M FrongneUX, G. GASPARINI, L. MARTEL, G. PATAU, M. SICILIANO and A. CISTERNAS (1988): The Perugia (Italy) earthquake of 29, April 1984: a microearthquake survey, Bull. Seismol. Soc. Am., 78, 1948-1964.

HANCOCK, P.L. (1985): Brittle microtectonics: principles and practise, J. Struct. Geol., 7, 437-457.

HATZFELD, D., V. KARAKOSTAS, M. ZiAZIA, I. KASSARAS, E. PAPADIMITRIOU, K. MAKROPOUlOS, N. Voulgaris and C. PAPAIOANNOU (2000): Microseismicity and faulting geometry in the Gulf of Corinth (Greece), Geophys. J. Int., 141, 438-456.

HubBERT, M.K. and W.W. RUBEY (1959): Role of fluid pressure in mechanics of overthrust faulting, Geol. Soc. Am. Bull., 70, 115-160.

JAEGER, J.C. and N.G. W.COOK (1979): Fundamentals of Rock Mechanics (Methuen, London), 3rd ed., pp. 593.

JOHN, B.E. and D.A. FOSTER (1993): Structural and thermal constraints on the initiation angle of detachment faulting in the southern basin and range: the Chemehuevi Mountains study, Geol. Soc. Am. Bull., 105, 1091-1108.

Jolivet, L., C. Faccenna, B. Goffé, M. Mattei, F. Rossetti, C. BRUnet, F. StORTi, R. Funiciello, J.P. CAdet, N. D'Agostino and T. PARRA (1998): Midcrustal shear zones in postorogenic extension: example from the Northern Tyrrhenian Sea, J. Geophys. Res., 103, 12123-12160.

KELLER, J.V.A., G. MinELLI and G. PIALLI (1994): Anatomy of late orogenic extension: the Northern Apennines case, Tectonophysics, 238, 275-294.

LAVECCHIA, G., F. BROZZETTI, M.R. BARCHI, J. KELLER and M. MenicheTti (1994): Seismotectonic zoning in EastCentral Italy deduced from the analysis of the Neogene to present deformations and related stress fields, Bull. Geol. Soc. Am., 106, 1107-1120.

Lister, G.S. and G.A. DAVIS (1989): The origin of metamorphic core complexes and detachment faults formed during Tertiary continental extension in the Northern Colorado River region, U.S.A., J. Struct. Geol., 11, 65-93.

Lister, G.S., G. BANGA and A. FeEnSTRA (1984): Metamorphic core complexes of Cordilleran type in the Cyclades, Aegean Sea, Greece, Geology, 12, 221-225.

MARIUCCI, M.T., A. AMATO and P. MONTONE (1999): Recent tectonic evolution and present stress in the Northern Apennines, Tectonics, 18, 108-118.

Marson, I., L. Cernobori, R. Nicolich, M. Stoka, D. LIOTTA, F. PALMIERI and I. VELICOGNA (1998): CROP03 profile: a geophysical analysis of data and results, Mem. Soc. Geol. Ital., 52, 123-137.

Miller, S.A., A. Nur and D.L. OlgaARd (1996): Earthquakes as coupled shear stress-high pore pressure dynamical system, Geophys. Res. Lett., 23, 197-200.

Minelli, G. (1992): Tectonic Evolution of the Perugia Massif Area, Northern Apennines (Italy), Unpubl. Ph. D. Thesis, Imperial College, London, pp. 158.

Minissale, A., G. Magro, G. MARTinelli, O. VAselli and G.F. TASSI (2000): Fluid geochemical transect in the Northern Apennines, (Central-Northern Italy): fluid genesis and migration and tectonic implications, Tectonophysics, 319, 199-222.
MongelLi, F. and G. ZiTo (1991): Flusso di calore nella regione Toscana, Studi Geologici Camerti, special issue 1991/1, 91-98

MORLEY, C.K. (1999): Marked along-strike variations in dip of normal faults-the Lokichar fault, N. Kenya rift: a possible cause for metamorphic core complexes, J. Struct. Geol., 21, 479-492.

Morrow, C., B. RADLEY and J.D. ByerleE (1992): Frictional strength and the effective pressure law for montmorillonite and illite clays, in Fault Mechanics and Transport Properties of Rock, edited by B. EvANS and T.F WONG (Academic Press, London), 69-88.

Ofoegbu, G.I. and D.A. FerRILL (1998): Mechanical analyses of listric normal faulting with emphasis on seismicity assessment, Tectonophysics, 284, 65-77.

PARRY, W.T. and R.L. BRUHN (1990): Fluid pressure transients on seismogenic normal faults, Tectonophysics, 179, 335-344.

PASCUCCI, V., S. MERLINI and I.P. MARTINI (1999): Seismic stratigraphy in the Miocene-Pleistocene sedimentary basins of the Northern Tyrrhenian Sea and Western Tuscany (Italy), Basin Res., 11, 337-356.

PAuselli, C. and C. FeDERICO (2002): The brittle/ductile transition along the CROP03 seismic profile: relationships with the geological features, in Atti del Convegno "Evoluzione Geologica e Geodinamica dell'Appennino», in memoria di Giampaolo Pialli, Boll. Soc. Geol. Ital., 1, 25-35.

PIALLI, G., M.R. BARCHI and G. Minelli (1998): Results of the CROP03 deep seismic reflection profile, Mem. Soc. Geol. Ital., 52, pp. 657.

PONZIANi, F., R. DE Franco, G. Minelli, G. Biella, C. FEDERICO and G. PIALLI (1995): Crustal shortening and duplication of the Moho in the Northern Apennines: a view from seismic refraction data, Tectonophysics, 252, 391-418.

ProffeTt, J.M. (1977): Cenozoic geology of the Yerington district, Nevada, and implications for the nature of basin and range faulting, Geol. Soc. Am. Bull., 88, 247-266.

REUTTER, K.J., P. GIESE and H. CLOSS (1980): Lithospheric split in the descending plate: observations from the Northern Apennines, Tectonophysics, 64, T1-T9.

RiETBRock, A., C. TIBERI, F. SCHERBAUM and H. LYONCAEN (1996): Seismic slip on a low-angle normal fault in the Gulf of Corinth: evidence from high-resolution cluster analysis of microearthquakes, Geophys. Res. Lett., 23, 1817-1820.

Rigo, A., H. Lyon-CAen, R. ARmiJo, A. Deschamps, D. HATZFELD, K. MAKROPOULOS, P. PAPADIMITRIOU and I. KASSARAS (1996): A microseismic study in the western part of the Gulf of Corinth (Greece): implications for large-scale normal faulting mechanisms, Geophys. J. Int., 126, 663-688.

Royden, L. and G.D. KARNER (1984): Flexure of the litosphere beneath Apennine and the Carpathian foredeep basins: evidence for an insufficient topographic load, Am. Assoc. Petr. Geol. Bul., 68, 704-712.

RUBIN, A.M., D. GILLARD and J.L. GOT (1999): Streaks of microseismicity along creeping faults, Nature, 400, 635-641.

ScHOLZ, C.H. (1998): Earthquakes and friction laws, Nature, 391, 37-42. 
SCOTT, R.J. and G.D. LISTER (1992): Detachment faults: evidence for a low-angle origin, Geology, 20, 833-836.

Seront, B., T-F. Wong, J.S. CAine, C.B. Forster, R.L. BRUHN and J.T. FREDRICH (1998): Laboratory characterisations of hydromechanical properties of a seismogenic normal fault system, J. Struct. Geol., 20, 865-882.

SIBSON, R.H. (1985): A note on fault reactivation, J. Struct. Geol., 7, 751-754.

SIBSON, R.H. (1989): Earthquake faulting as a structural process, J. Struct. Geol., 11, 1-14.

SIBSON, R.H. (1990): Rupture nucleation on unfavourably oriented faults, Bull. Seismol. Soc. Am., 80, 1580-1604.

SIBSON, R.H. (1993): Load-strengthening versus loadweakening faulting, J. Struct. Geol., 15, 123-128.

SIBSON, R.H. (2000): Fluid involvement in normal faulting, in The Resolution of Geological Analysis and Models for Earthquake Faulting Studies, edited by G. CELLO and E. TONDI, J. Geodyn., 29, 469-499.

SOREL, D. (2000): A Pleistocene and still-active detachment fault and the origin of the Corinth-Patras rift, Greece, Geology, 28, 83-86.

SuHAdOLC, P. and G.F. PANZA (1989): Physical properties of the lithosphere-astenosphere system in Europe from geophysical data, in The Lithosphere in Italy, edited by A. Boriani, M. BonAfEDE, G.B. PICCARDO and G.B. VAI, Accad. Naz. Lincei, Roma, Adv. Earth. Sci. Res., 80, $15-40$.

TAYLOR, B., A.M. GOODLIFFE and F. MARTINEZ (1999): How continents break up: insights from Papua New Guinea,
J. Geophys. Res., 104, 7497-7512.

TOWNEND, J. and M.D. ZOBACK (2000): How faulting keeps the crust strong, Geology, 28, 399-402.

TOWNEND, J. and M.D. ZOBACK (2001): Implications of earthquake focal mechanisms for the frictional strength of the San Andreas fault system, Geol. Soc. London, Spec. Pub., 186, 13-21.

Vaselli, O., F. Tassi, A. Minissale, B. CAPaCCIONI, G. MAGRO and W.C. EvANS (1997): Geochemistry of natural gas manifestations from the upper Tiber Valley (Central Italy), Miner. Petrog. Acta, 40, 201-212.

WERNICKE, B.P. (1981): Low-angle normal faults in the Basin and Range Province: nappe tectonics in an extending orogene, Nature, 291, 645-648.

WERNICKE, B. (1995): Low-angle normal faults and seismicity: a review, J. Geophys. Res., 100, 20,15920,174 .

WERNICKE, B. and G.J. AXEN (1988): On the role of isostasy in the evolution of normal fault systems, Geology, 16, 848-851.

WestawAy, R. (1999): The mechanical feasibility of lowangle normal faulting, Tectonophysics, 308, 407-443.

Westaway, R., R. GAWTHORPE and M. TOZZI (1989): Seismological and field observations of the 1984 LazioAbruzzo earthquakes: implications for the active tectonics of Italy, Geophys. J. Int., 98, 489-514.

(received June 18, 2002;

accepted October 21, 2002) 